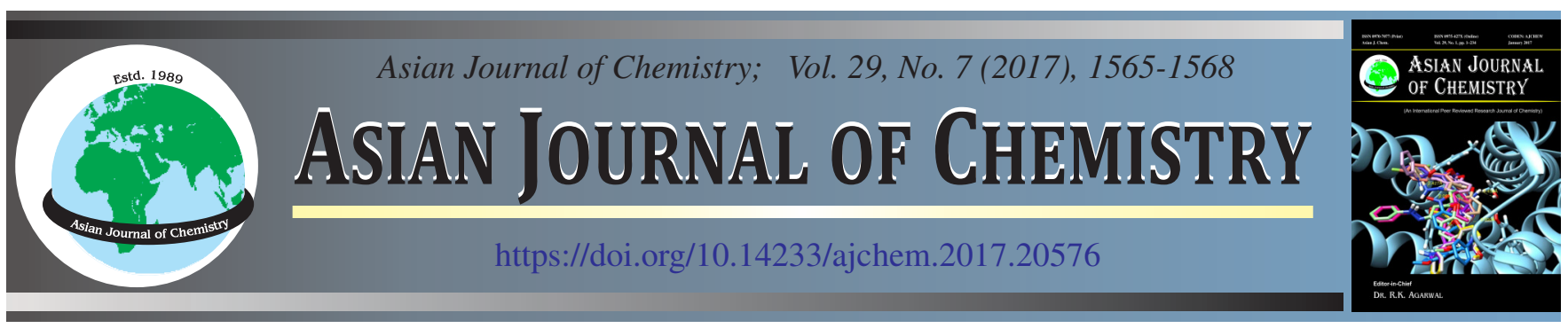

\title{
Analytical Validation and Comparative Study of HPLC, Spectrophotometric and Titration Method for Determination of Benzoic Acid in Food Products
}

\author{
Samarth I. Zarad*, Nitin R. Nimkar, Kishor R. Desai, Maheshwari S. Solanki, Devang M. Gandhi, \\ Harshal M. Gandhi, Monali S. Patel, Aparna A. Khimani and Macky N. Suraliwala
}

Department of Quality Control, Pollucon Laboratories Pvt. Ltd., Surat-395 003, India

*Corresponding author: E-mail: samarthzarad@gmail.com

Received: 8 February 2017;

Accepted: 27 March 2017;

Published online: 13 May 2017;

AJC-18394

\begin{abstract}
The objective of this work was to validate the analytical method and evaluate the detection limit of benzoic acid in food with using chromatographic, spectroscopic and titration techniques. An experiment was carried out by spiking benzoic acid in tomato ketchup and benzoic acid was extracted in methanol and analyzed by HPLC, UV-visible spectrophotometer and titration method. In HPLC method S/N ratio of standard benzoic acid was observed 3:1 at $1 \mu \mathrm{g} / \mathrm{mL}$ concentration and 10:1 at $4 \mu \mathrm{g} / \mathrm{mL}$ concentration of benzoic acid, Hence LOD and LOQ of benzoic acid were 1 and $4 \mu \mathrm{g} / \mathrm{mL}$, respectively. The coefficient of correlation value (r) was 0.9998 for standard benzoic acid in concentration range of $10,50,100,500$ and $1000 \mu \mathrm{g} / \mathrm{mL}$. The recovery of spiked standard benzoic acids in tomato ketchup sample was observed in the range of 98.83-100.47 \%. The $\lambda_{\max }$ of standard benzoic acid was observed at $230 \mathrm{~nm}$. In spectrophotometric method, coefficient of correlation value $\mathrm{r}=0.9995$ for standard benzoic acid in the range of $1,3,5,8$ and $10 \mu \mathrm{g} / \mathrm{mL}$ concentration was observed. Recovery of spiked standard benzoic acid in ketchup sample was observed between 97.25-99.54\%. With using titration technique, determined LOD was $\geq 50 \mu \mathrm{g} / \mathrm{mL}$. Coefficient of correlation value $\mathrm{r}=0.9993$ was obtained for standard benzoic acid at 5 level calibration concentration in the range of $50,100,150,200$ and $250 \mu \mathrm{g} / \mathrm{mL}$ recovery of standard benzoic acid in spiked sample was between 97.48 $98.98 \%$. This work indicates the selection of analytical method for benzoic acid determination as per the required detection limit (DL) in food products. RP-HPLC method can be used for detection limit of benzoic acid in the range of $1 \mu \mathrm{g} / \mathrm{mL}$ to above concentration. UVvisible spectrophotometric method can be used for benzoic acid analysis in the range of $1 \mu \mathrm{g} / \mathrm{mL}$ to $10 \mu \mathrm{g} / \mathrm{mL}$ concentration. Titration technique can be useful for $\geq 50 \mu \mathrm{g} / \mathrm{mL}$ concentration of benzoic acid in food products.
\end{abstract}

Keywords: Benzoic acid, HPLC, UV-visible spectrophotometer, Titration, Food product.

\section{INTRODUCTION}

In early $20^{\text {th }}$ Century, Consumers become more quality conscious towards the processed food. Demands of high quality packaged food have changed the scenario of food processing industries. Achieving high quality food product with possible self-life is always a challenging part for food industries. In order to assure the food quality, chemical preservatives are commonly added in processed food. Benzoic acid is widely used as a food preservative as it possessed significant characteristic to inhibits the growth of yeast, bacteria and fungus [1-3]. As per the regulatory guideline of WHO, USEPA and FSSAI for food safety, quantification of benzoic acid in processed food is a mandatory parameter $[4,5]$.

In present paper HPLC, spectrophotometric and titration methods were developed and validated for determination of benzoic acid. In extraction process, spiked benzoic acid in tomato ketchup sample was saturated with $\mathrm{NaCl}$ and followed by acidification with dil. $\mathrm{HCl}$ and extracted in chloroform. Chloroform was evaporated and residue of benzoic acid was collected by dissolving in methanol [4]. HPLC method is highly recommended to produce effective resolution and separation of benzoic acid. Ammonium acetate buffer adjusted pH 2.5 with acetic acid and methanol composition was used as a mobile phase. $\mathrm{C}_{18}$ column with the column dimension of $150 \mathrm{~mm} \times 4.6 \mathrm{~mm}, 5 \mu$ particle size was used as a stationary phase [4]. UV-visible spectrophotometric method is also useful for determination of benzoic acid with specific detection limits. Spectroscopic scan of benzoic acid at UV region produce maximum absorbance $\lambda_{\max }$ at $230 \mathrm{~nm}$. Extracted benzoic acid sample was scanned at $230 \mathrm{~nm}$ wavelength [6,7]. Titration of extracted benzoic acid against sodium hydroxide using phenolphthalein as an indicator was an effective method for the detection limit $\geq 50$ ppm of benzoic acid [4]. 


\section{EXPERIMENTAL}

Methanol, chloroform, acetic acid, sodium hydroxide, ammonium acetate, potassium hydrogen phthalate, benzoic acid, sodium sulphate, sodium chloride, distilled water, hydrochloric acid and phenolphthalein indicator. Tomato ketchup was purchased from local market. All the chemicals and reagents were stored at $25 \pm 2{ }^{\circ} \mathrm{C}$ and $40 \%$ relative humidity controlled room temperature.

Extraction of benzoic acid from tomato ketchup: Weigh about $200 \mathrm{~g}$ of tomato ketchup sample in three $500 \mathrm{~mL}$ beakers, spiked 100,300 and $500 \mu \mathrm{g} / \mathrm{mL}$ concentration of standard benzoic acid in three tomato ketchup samples, respectively, $10 \mathrm{~g}$ of $\mathrm{NaCl}$ was added and mixed well with using glass road, after that transferred the sample in to $250 \mathrm{~mL}$ of flask. Saturated $\mathrm{NaCl}$ solution was added to make up the volume up to $250 \mathrm{~mL}$, kept that solution for $1 \mathrm{~h}$ in dark with occasional shaking. After that solution was filtered and filtrate was used for analysis [4]. Prepared total three spiked samples of 100, 300 and $500 \mu \mathrm{g} / \mathrm{mL}$ concentration of standard benzoic acid in tomato ketchup and repeated the extraction and analysis process with using HPLC, spectroscopic and titration method.

\section{Analysis procedure}

Preparation of $0.1 \mathrm{~N}$ potassium hydrogen phthalate solutions: Dry about $25 \mathrm{~g}$ of potassium hydrogen phthalate (KHP) at $105 \pm 5^{\circ} \mathrm{C}$ for $3 \mathrm{~h}$ then placed potassium hydrogen phthalate in desiccators for $0.5 \mathrm{~h}$. Accurately weigh about $10.211 \mathrm{~g}$ of dried potassium hydrogen phthalate and dissolve in distilled water and dilute to $500 \mathrm{~mL}$.

Preparation of $0.05 \mathrm{~N} \mathrm{NaOH}$ solution: Dissolved $3 \mathrm{~g}$ of $\mathrm{NaOH}$ pellets in $1000 \mathrm{~mL}$ of distilled water. $10 \mathrm{~mL}$ of $0.1 \mathrm{~N}$ potassium hydrogen phthalate was titrated against $\mathrm{NaOH}$ solution. Few drops of phenolphthalein were used as an indicator. Colour change was observed from colourless solution to pink colour. Standardization process was repeated in triplicate and took the mean value as a normality of $\mathrm{NaOH}$.

Sample preparation: $200 \mathrm{~mL}$ of extracted sample was taken in to the $500 \mathrm{~mL}$ beaker, then $5 \mathrm{~mL}$ concentrated $\mathrm{HCl}$ was added in order to acidify the solution. After that sample was transferred to $500 \mathrm{~mL}$ separatory funnel followed by adding $50 \mathrm{~mL}$ of chloroform. Benzoic acid was collected in chloroform layer by shaking the separatory funnel. After shaking chloroform layer was collected in second $250 \mathrm{~mL}$ separatory funnel and washed with distilled water. At last transferred the chloroform layer in to the evaporating dish and allowed it to dry at room temperature, after that benzoic acid residues was collected with dissolving it in methanol [4].

Preparation of standard solution of benzoic acid: Prepared $2000 \mu \mathrm{g} / \mathrm{mL}$ benzoic acid stock solution in methanol, use this stock solution for HPLC analysis. For UV-visible spectrophotometric analysis, $1,3,5,8$ and $10 \mu \mathrm{g} / \mathrm{mL}$ of benzoic acid working standard was prepared from $100 \mu \mathrm{g} / \mathrm{mL}$ standard benzoic acid.

RP-HPLC method for quantification of benzoic acid: HPLC with UV detector, instrument model no 1220 LC solution of Agilent Technologies was used for identification and quantification of benzoic acid (Table-1). Calibration standard were prepared in methanol at 5 levels in the range of 10, 50, 100, 500 and $1000 \mu \mathrm{g} / \mathrm{mL}[4,8-10]$.
TABLE-1

HPLC CHROMATOGRAPHIC CONDITIONS

\begin{tabular}{ll}
\hline Column & $\begin{array}{l}\mathrm{C}-18,150 \mathrm{~mm} \times 4.6 \mathrm{~mm}, 5 \mu \mathrm{m} \text { particle } \\
\text { size }\end{array}$ \\
Mobile phase A & Methanol \\
Mobile phase B (buffer) & $\begin{array}{l}\text { Dissolve } 3.89 \mathrm{~g} \text { ammonium acetate in } \\
1000 \mathrm{~mL} \text { of distilled water, adjust } \mathrm{pH}\end{array}$ \\
& 2.5 with acetic acid \\
& Mobile phase A $35 \%$ and mobile phase \\
Isocratic program & $\mathrm{B} 65 \%$ \\
& $0.7 \mathrm{~mL} / \mathrm{min}$ \\
Flow rate & $254 \mathrm{~nm}$ \\
Detection wavelength & $50 \mu \mathrm{L}$ of sample \\
Injection volume & $30 \mathrm{~min}$ \\
Run time & $27^{\circ} \mathrm{C}$ \\
Column oven temperature
\end{tabular}

UV-visible spectophotometric method for determination of benzoic acid: Carry 630 UV-visible spectrophotometer of Agilent Technologies was used for analysis of benzoic acid. Extracted sample was further diluted by taking $1 \mathrm{~mL}$ of extracted sample and dilute to $100 \mathrm{~mL}$ with methanol [6,7]. Calibration standard were prepared by diluting $100 \mu \mathrm{g} / \mathrm{mL}$ standard solution of benzoic acid with methanol at 5 levels in the range between $1,3,5,8$ and $10 \mu \mathrm{g} / \mathrm{mL}$. Sample and calibration standards were scanned at the wavelength of 230 nm.

Titration method for determination of benzoic acid: Titrate the extract against $0.05 \mathrm{~N}$ sodium hydroxide using phenolphthalein as an indicator. Calibration standard were prepared in methanol at 5 levels in the range of 50, 100, 150, 200 and $250 \mu \mathrm{g} / \mathrm{mL}$ concentration of standard benzoic acid.

\section{RESULTS AND DISCUSSION}

Separation, detection range, linearity of calibration standard and recovery of benzoic acid with using HPLC method: RP-HPLC with UV-visible detector was enough sensitive to determine the benzoic acid. Following the HPLC chromatographic conditions we found the retention time (RT) of standard benzoic acid at $7.611 \mathrm{~min}$ (Fig. 1). Signal to noise ratio $(\mathrm{S} / \mathrm{N})$ has been observed $3: 1$ at $1 \mu \mathrm{g} / \mathrm{mL}$ and $10: 1$ at $4 \mu \mathrm{g} /$ $\mathrm{mL}$ concentration of standard benzoic acid. Obtained retention time of benzoic acid in three spiked sample was 7.593, 7.689 and $7.697 \mathrm{~min}$, respectively [Figs. (2-4)]. The recovery of three spiked sample was in between 98.83-100.47\%.

Detection range, linearity of calibration standard and recovery of benzoic acid with using UV-visible spectrophotometer: UV-visible spectrophotometer is suitable for determining the benzoic acid content in food products in the range of 1 to $10 \mu \mathrm{g} / \mathrm{mL}$. The recovery of spiked sample was between $97.25-99.54 \%$ (Fig. 5).

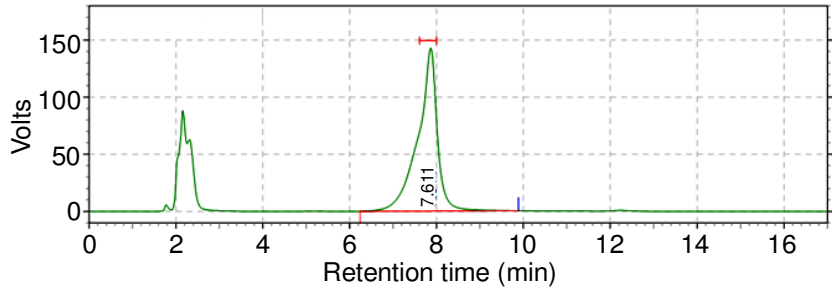

Fig. 1. HPLC chromatogram of standard benzoic acid (Retention time of standard benzoic acid was observed at $7.611 \mathrm{~min}$ ) 


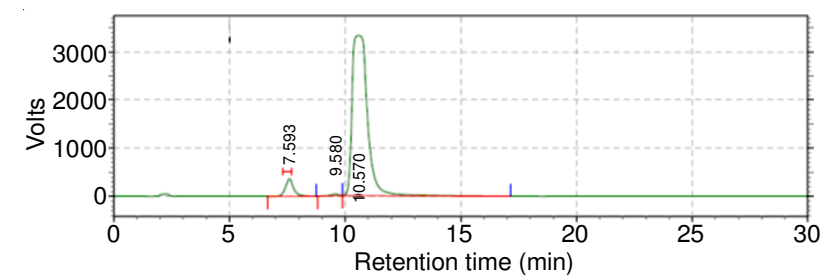

Fig. 2. HPLC chromatogram of spiked benzoic acid in tomato ketchup sample No. 1 [Retention time of benzoic acid in spiked sample was observed at $7.593 \mathrm{~min}$. Retention times of unknown peaks in tomato ketchup sample were observed at 9.580 and $10.570 \mathrm{~min}$ ]

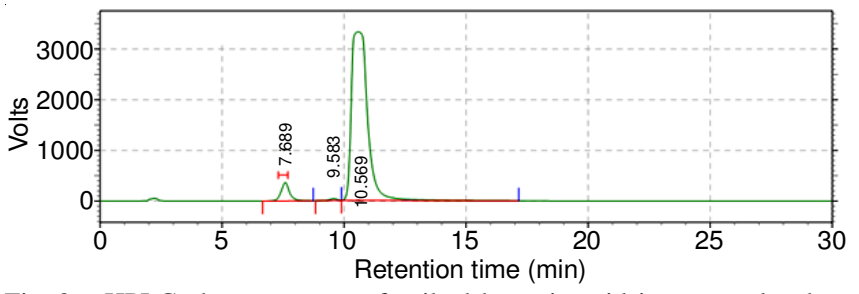

Fig. 3. HPLC chromatogram of spiked benzoic acid in tomato ketchup sample No. 2 [Retention time of benzoic acid in spiked sample was observed at $7.689 \mathrm{~min}$. Retention times of unknown peaks in tomato ketchup sample were observed at 9.583 and $10.569 \mathrm{~min}]$

Detection range and recovery of benzoic acid by titration method: $0.1 \mathrm{~mL}$ of burette reading was taken as a minimum

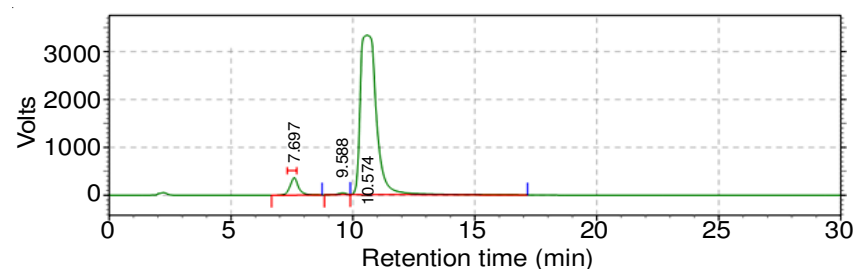

Fig. 4. HPLC Chromatogram of spiked benzoic acid in tomato ketchup sample No. 3 [Retention time of benzoic acid in spiked sample was observed at $7.697 \mathrm{~min}$. Retention times of unknown peaks in tomato ketchup sample were observed at 9.588 and $10.574 \mathrm{~min}]$

burette reading for determination of lowest detection limit. The detection limit was observed $50 \mu \mathrm{g} / \mathrm{mL}$ and calculated recovery of spiked sample was between $97.48-98.98 \%$.

\section{Conclusion}

The proposed HPLC, spectroscopic and titration method were successfully validated with the parameters such as accuracy, precision, repeatability, LOD, LOQ, recovery, linearity and specificity (Table-2). Comparative study of these methods gives wide selectivity to adopt one of the proposed methods without any interference for determination of benzoic acid in food.

\begin{tabular}{|c|c|c|c|c|c|c|}
\hline \multicolumn{7}{|c|}{$\begin{array}{c}\text { TABLE-2 } \\
\text { PRECISION, REPEATABILITY AND ACCURACY AND RECOVERY }\end{array}$} \\
\hline Method & $\begin{array}{l}\text { Conc. of benzoic } \\
\text { acid (ppm) }\end{array}$ & $\begin{array}{l}\text { Sample } \\
\text { No. }\end{array}$ & $\begin{array}{l}\text { Mean value of benzoic } \\
\text { acid obtained (ppm) } \\
n=5\end{array}$ & $\begin{array}{l}\text { Mean value of } \\
\text { benzoic acid \% } \\
\text { recovery }\end{array}$ & $\begin{array}{l}\% \text { RSD of benzoic } \\
\text { acid concentration }\end{array}$ & $\begin{array}{l}\text { Retention time } \\
\text { repeatability } \\
(\% \mathrm{RSD})\end{array}$ \\
\hline \multirow{9}{*}{ HPLC } & \multirow{3}{*}{100} & 1 & 99.47 & 99.47 & 0.65 & 0.97 \\
\hline & & 2 & 98.83 & 98.83 & 0.58 & 1.24 \\
\hline & & 3 & 100.47 & 100.47 & 0.69 & 1.08 \\
\hline & \multirow{3}{*}{300} & 1 & 298.59 & 99.53 & 0.72 & 1.57 \\
\hline & & 2 & 299.67 & 99.89 & 0.44 & 1.22 \\
\hline & & 3 & 297.23 & 99.08 & 0.82 & 1.41 \\
\hline & \multirow{3}{*}{500} & 1 & 498.7 & 99.74 & 0.75 & 1.11 \\
\hline & & 2 & 497.2 & 99.44 & 0.58 & 0.92 \\
\hline & & 3 & 496.2 & 99.24 & 0.74 & 1.08 \\
\hline Method & $\begin{array}{l}\text { Conc. of benzoic } \\
\text { acid (ppm) }\end{array}$ & $\begin{array}{l}\text { Sample } \\
\text { No. }\end{array}$ & $\begin{array}{l}\text { Mean value of benzoic } \\
\text { acid obtained (ppm) } \\
\qquad n=5\end{array}$ & $\begin{array}{l}\text { Mean value of } \\
\text { benzoic acid \% } \\
\text { recovery }\end{array}$ & $\begin{array}{l}\% \text { RSD of benzoic } \\
\text { acid concentration }\end{array}$ & $\begin{array}{l}\text { Absorbance unit } \\
\text { repeatability } \\
(\% \mathrm{RSD})\end{array}$ \\
\hline \multirow{9}{*}{ Spectroscopic } & \multirow{3}{*}{100} & 1 & 98.54 & 98.54 & 0.95 & 0.18 \\
\hline & & 2 & 97.25 & 97.25 & 1.12 & 0.26 \\
\hline & & 3 & 97.92 & 97.92 & 0.72 & 0.14 \\
\hline & \multirow{3}{*}{300} & 1 & 296.64 & 98.88 & 0.88 & 0.22 \\
\hline & & 2 & 298.63 & 99.54 & 0.77 & 0.20 \\
\hline & & 3 & 297.92 & 99.31 & 0.68 & 0.16 \\
\hline & \multirow{3}{*}{500} & 1 & 494.2 & 98.84 & 0.97 & 0.57 \\
\hline & & 2 & 493.4 & 98.68 & 0.88 & 0.66 \\
\hline & & 3 & 495.3 & 99.06 & 0.82 & 0.23 \\
\hline Method & $\begin{array}{l}\text { Conc. of benzoic } \\
\text { acid (ppm) }\end{array}$ & $\begin{array}{l}\text { Sample } \\
\text { No. }\end{array}$ & $\begin{array}{l}\text { Mean value of benzoic } \\
\text { acid obtained (ppm) } \\
n=1\end{array}$ & $\begin{array}{l}\text { Mean value of } \\
\text { benzoic acid \% } \\
\text { recovery }\end{array}$ & $\begin{array}{l}\% \text { RSD of benzoic } \\
\text { acid concentration }\end{array}$ & $\begin{array}{l}\text { Burette reading } \\
\text { repeatability of three } \\
\text { samples }(\% \mathrm{RSD})\end{array}$ \\
\hline \multirow{9}{*}{ Titration } & \multirow{3}{*}{100} & 1 & 97.48 & 97.48 & \multirow{3}{*}{0.59} & \multirow{3}{*}{0.16} \\
\hline & & 2 & 97.64 & 97.64 & & \\
\hline & & 3 & 98.55 & 98.55 & & \\
\hline & \multirow{3}{*}{300} & 1 & 296.95 & 98.98 & \multirow{3}{*}{0.74} & \multirow{3}{*}{0.17} \\
\hline & & 2 & 292.88 & 97.63 & & \\
\hline & & 3 & 293.54 & 97.85 & & \\
\hline & \multirow{3}{*}{500} & 1 & 490.2 & 98.04 & \multirow{3}{*}{0.12} & \multirow{3}{*}{0.10} \\
\hline & & 2 & 491.4 & 98.28 & & \\
\hline & & 3 & 490.8 & 98.16 & & \\
\hline
\end{tabular}



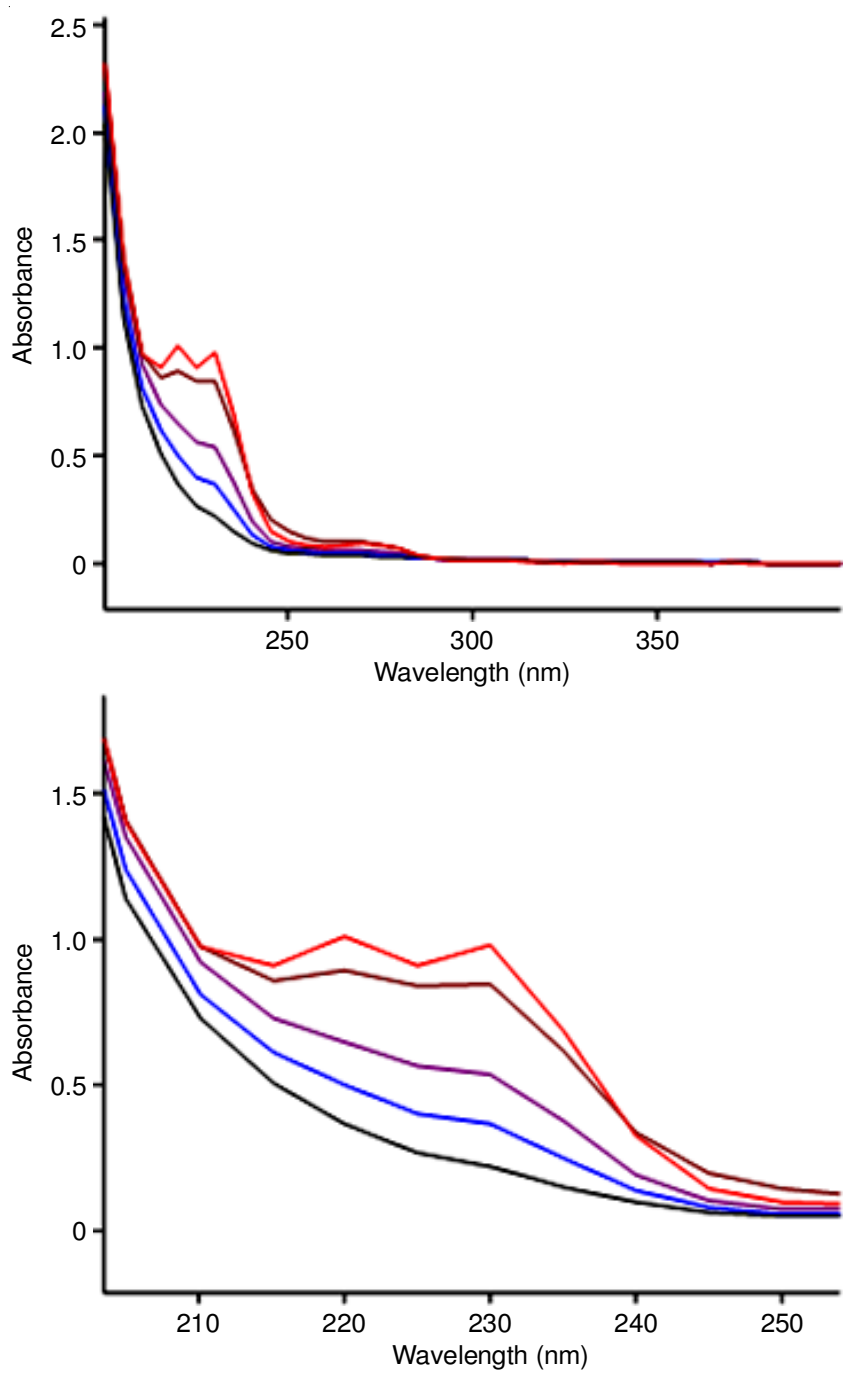

Fig. 5. UV-visible spectroscopic scan of benzoic acid the concentration of $1.0,3.0,5.0,8.0$ and $10 \mathrm{ppm}$ shows the $\lambda_{\max }$ at $230 \mathrm{~nm}$

\section{ACKNOWLEDGEMENTS}

Sincere gratitude to Pollucon Laboratories Pvt. Ltd, Surat, India for funding the project and supporting the work.

\section{REFERENCES}

1. N.J. Russell and G.W. Gould, Food Preservatives, Kluwer Academic/ Plenum Publishers, New York (2003).

2. H.A. Krebs, D. Wiggins, M. Stubbs, A. Sols and F. Bedoya, Biochem. J., 214, 657(1983); https://doi.org/10.1042/bj2140657.

3. P.M. Davidson, J.N. Sofos and A.L. Branen, Antimicrobials in Food, Taylor and Francis Group, edn 3, pp. 18 (2005).

4. FSSAIF, Manual of Method of Analysis of Food Additives, Lab Manual 8, Food Safety and Standards Authority of India, Ministry of Health and Family Welfare, Government of India, pp. 4-13 (2015).

5. World Health Organization (WHO), Benzoic Acid and Sodium Benzoate, Geneva, USA, doc. 26 (2000).

6. V.L. McDevitt, A. Rodriguez and K.R. Williams, J. Chem. Educ., 75, 625 (1998); https://doi.org/10.1021/ed075p625.

7. R. Koplik, Advanced Strategies in Food Analysis, In: Ultraviolet and Visible Spectrometry, p. 5 (2001).

8. C.P. Ene and E. Diacu, U.P.B. Sci. Bull., Series B, 71, 81 (2009).

9. B. Saad, M.F. Bari, M.I. Saleh, K. Ahmad and M.K.M. Talib, J. Chromatogr. A, 1073, 393 (2005); https://doi.org/10.1016/j.chroma.2004.10.105.

10. J. Burana-osot, L. Arunsingkharat, M. Naksuk, S. Naungnamjai and T. Saetun, Chiang Mai J. Sci., 41, 370 (2014). 